\title{
THE DETERMINATION OF BIOACTIVE INGREDIENTS OF GRAPE POMACE (VRANAC VARIETY) FOR POTENTIAL USE IN FOOD AND PHARMACEUTICAL INDUSTRIES
}

Marko Anđelković ${ }^{*}$ Blaga Radovanović1, Ana Milenković Anđelković1, Vladimir Radovanović1, Aleksandra Zarubica1 ${ }^{1}$ Nikola Stojković1 ${ }^{1}$ Vesna Nikolić ${ }^{2}$

${ }^{1}$ Faculty of Science and Mathematics, Department of Chemistry, University of Niš, Niš, Serbia

2Faculty of Technology, University of Niš, Leskovac, Serbia

Wine production generated significant quantities of waste - grape pomace (seeds, skin and stems of grapes). In these vinification by-products a significant amount of bioactive compounds such as phenol compounds can still be found. The phenol composition and radical scavenging activity of grape pomace obtained during winemaking from the red wine grape of Vranac variety (Vitis vinifera L.) were investigated to determine their usable values. Reversephase high performance liquid chromatography (RP-HPLC) assays were used for determination of the phenolic composition of pomace extracts and the DPPH test was done for their radical scavenging activity. The oil obtained from the pomace was subjected to GC/MS analysis in order to establish its fatty acid composition. As correlation calculations showed $\left(R^{2}=0.9732\right)$, phenol compounds are responsible for strong radical scavenging activities of the tested extracts $(1.160 \pm 0.03 \mathrm{mg} \mathrm{DM} / \mathrm{ml})$. Grape pomace oil with a high degree of of unsaturation (over $88 \%$ ) plays an important role for human health. The phenolic rich extract and grape pomace oil can be used as additives in food and pharmacy industries.
(ORIGINAL SCIENTIFIC PAPER) UDC 663.26:66.061.34
Keywords: grape pomace, grape seed, phenolic compounds, radical scavenging activity, fatty acids.

\section{Introduction}

Grape wine (genus Vitis) is considered the world's most abundant fruit crop. Grapes and wine are rich in phenolic compounds which are very important for human health as compounds with antioxidant, anti-cancer, anti-inflammatory and antimicrobial activities [1-3]. There are also studies on the beneficial effects of those compounds on the heart and other chronic diseases [4]. During the processing of grapes into wine, a significant amount of phenolic compounds (soluble in water) passes into wine. But also a certain amounts of these compounds remain in the pomace. On the other hand, grapes and pomace also have a certain amount of vegetable oil which is found in grape seeds, but also in other parts of grapevine as stems [5]. The wine production generated significant quantities of waste (seeds, skins and stems of grapes). This waste was usually used for the production brandy and fertilizer. The phenol composition and antioxidant activity of grape extracts have been well documented [1-4, 6], and there is less data about pomace [79]. Also, there were few reports about vegetable oils from grape seeds, and their health benefits, [10] but no reports about the whole grape pomace.

The aim of this study was to determine the extraction yield of phenolics and vegetable oils, their composition and antioxidant activity of the phenolic extract from the grape pomace.

\section{Materials and Methods}

\section{Samples}

The wine pomace of red wine variety Vranac (Vitis vinifera L.) was taken from the "Aleksic” winery immediately after a 14-day vinification process. Maceration was performed with crushed grapes without stems. The samples of wine pomace (grape seeds and skins) were washed, dried at $60^{\circ} \mathrm{C}$ in the oven for $12 \mathrm{~h}$ and crushed in a grinder for 2 min., and then used for extractions.

\section{Chemicals}

Acetonitrile, methanol and formic acid of HPLC-grade were obtained from Merck (Darmstadt, Germany). The standard phenolic compounds and 2,2'-diphenyl-1-picrylhydrazyl free radical (DPPH) and all other chemicals were supplied from Sigma Chemical Co. (St. Louis, MO). The reagents used were of analytical quality.

\section{Extraction of phenolic compounds}

The samples (pomace) were weighed $(1 \mathrm{~g})$ and extracted with the $40 \mathrm{ml}$ solvent system of methanol/acetone/water/acetic acid (30/42/27.5/0.5), by stirring continuously at room temperature in the dark for $1 \mathrm{~h}$, and then centrifuged

\footnotetext{
* Author address: Marko Anđelković, Faculty of Science and Mathematics, Department of Chemistry, University of Niš, Višegradska 33, 18000 Niš, Serbia

E-mail: marko.andjelk@gmail.com

The manuscript received: June, 17, 2015.

Paper accepted: October, 13, 2015
} 
for $10 \mathrm{~min}$ at $2500 \mathrm{xg}$. The supernatants were collected and the precipitates were extracted again with the same solvent system. Combined extracts were evaporated to dryness under vacuum rotary evaporator below $50^{\circ} \mathrm{C}$ and diluted in methanol to the concentration of $0.1 \mathrm{~g} / \mathrm{ml}$.

\section{Extraction of grape pomace oil}

The powder of the grape pomace $(10 \mathrm{~g})$ was extracted in a Soxhlet extractor for $3 \mathrm{~h}$ with $200 \mathrm{ml}$ of hexane at $60^{\circ} \mathrm{C}$.

Spectrophotometric Determination of Phenolic Compo sition

Total phenolics, hydroxycinnamoyl tartaric acids and flavonols in selected extract samples were determined according to the spectrophotometric method previously described [11]. The results were expressed as milligrams $(\mathrm{mg})$ of gallic acid equivalents (GAE) for total phenols, $\mathrm{mg}$ of caffeic acid equivalents (CAE) for total hydroxycinnamoyl tartaric acids and $\mathrm{mg}$ of quercetin equivalents (QE) for total flavonols per gram (g) of the extract dry matter (DM).

Total anthocyanins were also determined spectrophotometrically [12]. Malvidin-3-glucoside was employed as a calibration standard and the results were expressed as $\mathrm{mg}$ malvidin-3-glucoside equivalents (ME) per $\mathrm{g}$ of the extract DM.

Reverse-phase High-Performance Liquid Chromatography Analyses

The phenol composition of the selected extracts was analyzed by reverse-phase high performance liquid chromatography (RP-HPLC) of the extracts. The analysis was carried out with an Agilent Technologies 1200 chromatographic system equipped with DAD - photodiode array and fluorescence detectors. The column (Agilent-Eclipse XDB $\mathrm{C}-184.6 \times 150 \mathrm{~mm}$ ) was thermostated at $30^{\circ} \mathrm{C}$. The solvents $A$ : formic acid/water $(5: 95 \mathrm{v} / \mathrm{v})$ and $B$ : acetonitrile/for$\mathrm{mic}$ acid/water $(80: 5: 15 \mathrm{v} / \mathrm{v})$ were used and the elution gradient were previously described [12]. The injection volume was $5 \mu \mathrm{L}$ and the flow rate was $0.9 \mathrm{~mL} / \mathrm{min}$. The detection wavelengths were $280,320,360$ and $520 \mathrm{~nm}$ for UV, and $275 / 322 \mathrm{~nm}(\lambda \mathrm{Ex} / \lambda \mathrm{Em})$ for fluorescence-detection. The phenolic compounds were identified by comparing their spectral characteristics and retention times with the data of the original reference standard compounds and with the data given in literature $[13,14]$. The calibration curves of standard phenolic compounds (five data points, $n=2$ ) were linear with $R^{2}=0.99$. The results were expressed as $\mathrm{mg} / \mathrm{g}$ extract DM.

\section{Determination of the Radical Scavenging Activity}

The antioxidant activity of all investigated extracts was estimated by determining the radical scavenging activity (RSA, \%) of the extracts by the DPPH test previously described [12]. The antioxidant activities of the investigated extracts were expressed as median efficient concentrations (EC50). This is the concentration of the extract ( $\mathrm{mg} /$ $\mathrm{ml}$ ) needed for a decrease in absorbance of the DPPH solution to $50 \%$.
Analysis of fatty acids

The fatty acid composition of the oil extract was determined by the gas chromatography mass spectrometry (GC/ MS) analysis. GC/MS analysis was performed in a HewlettPackard $6890 \mathrm{~N}$ gas chromatograph, equipped with a fused silica capillary column DB-5MS ( $5 \%$ phenyl methyl siloksan, $30 \mathrm{~m} \times 0.25 \mathrm{~mm}$, film thickness $0.25 \mu \mathrm{m}$, Agilent Technologies, USA) and connected with a 5975B MSD mass selective detector (Agilent Technologies, USA). The injector and interface were adjusted for the operation temperature at $250{ }^{\circ} \mathrm{C}$ and $300^{\circ} \mathrm{C}$, respectively. It was operated under the following conditions: oven temperature program, 120 ${ }^{\circ} \mathrm{C}$ for $1 \mathrm{~min}$; raised to $240{ }^{\circ} \mathrm{C}$ at the rate of $6{ }^{\circ} \mathrm{C} / \mathrm{min}$ and then kept at $240{ }^{\circ} \mathrm{C}$ for $15 \mathrm{~min}$; carrier gas, helium at flow rate of $15 \mathrm{~cm} / \mathrm{s}$; split ratio, $1 / 20 \mathrm{ml} / \mathrm{min}$. Fatty acids were identified on the basis of their retention times (comparison with standards) and spectra using the searchable El-MS spectra library.

\section{Statistical Analysis}

All experiments were performed in triplicate. The values are shown as means \pm standard deviation. Computations were realized using Origin software package version 8.0.

\section{Results and Discussion}

The results of the spectrophotometric analysis of the pomace extract are shown in Table 1. The applied spectrophotometric analysis provides fast information of the total phenol content in the tested extracts.

The results showed a significant phenol content in the tested extracts. Total anthocyanins were the most abundant, followed by hydroxycinnamoyl acids and flavonols. Anthocyanins originate from the colored samples i.e. grape skin which is part of the pomace. For both varieties, Merlot and Vranac, Katalinic et al. [7] found approximately the same total anthocyanins content in the skin extracts, around 739 $\mathrm{mg} / \mathrm{g} \mathrm{FW}$. lacopini et al. [15] reported that the total anthocyanins content of the skin extracts for 10 studied varieties ranged from 5.94 to $39.29 \mathrm{mg} / \mathrm{g}$ DW. Hydroxycinnamoyl acids and flavonols are the ingredients of grape skins and steams which are also parts of grape pomace.

In order to determine the phenol content and composition of the investigated extracts more precisely, the HPLC method was used. The results from Table 2 are in accordance with those obtained by spectrophotometric determination of phenolics (Table 1). 
Table 1. Phenolic content determined by spectrometric methods and radical scavenging activity (EC50) of Vranac wine pomace

\begin{tabular}{lc}
\hline Applied spectrophotometric analysis & Content \\
\hline Total phenolic mg/g DM & $67.40 \pm 0.38$ \\
Hydroxycinnamoyl acids $(\mathrm{mg} / \mathrm{g} \mathrm{DM})$ & $2.67 \pm 0.05$ \\
Flavonols mg/g DM & $1.89 \pm 0.02$ \\
Total anthocyanins $(\mathrm{mg} / \mathrm{g} \mathrm{DM})$ & $17.90 \pm 0.04$ \\
Antioxidant activity - EC $50(\mathrm{mg} \mathrm{DM} / \mathrm{ml})$ & $1.160 \pm 0.03$ \\
\hline
\end{tabular}

Gallic acid was the most abundant acid present in the tested extracts. Other identified phenolic acids were trans-coutaric and caffeic acid, mainly present in skin and skins of grape pomace extracts. Quercetin-glucoside and rutin were the most abundant flavonols in these extracts, but luteolin-glucoside, kaempherol-glucoside and quercetin were also present.

Table 2. Phenolic composition of the pomace from Vranac, red grape variety, determined by HPLC analysis

\begin{tabular}{|c|c|}
\hline Phenolic compound (mg/g DM) & Content \\
\hline Gallic acid & $3.33 \pm 0.07$ \\
\hline trans-Coutaric acid & $0.41 \pm 0.02$ \\
\hline Caffeic acid & $0.50 \pm 0.04$ \\
\hline Quercetin glucoside & $0.11 \pm 0.01$ \\
\hline Rutin & $0.15 \pm 0.01$ \\
\hline Luteolin glucoside & $0.06 \pm 0.02$ \\
\hline Kaempherol glucoside & $0.08 \pm 0.01$ \\
\hline Quercetin & $0.05 \pm 0.01$ \\
\hline$(+)$-Catechin & $3.84 \pm 0.12$ \\
\hline Procyanidins & $10.46 \pm 0.21$ \\
\hline (-)-Epicatechin & $1.22 \pm 0.05$ \\
\hline Delphinidin-3-glucoside & $1.03 \pm 0.02$ \\
\hline Cyanidin-3-glucoside & $0.27 \pm 0.01$ \\
\hline Petunidin-3-glucoside & $1.24 \pm 0.02$ \\
\hline Peonidin-3-glucoside & $1.11 \pm 0.01$ \\
\hline Malvidin-3-glucoside & $4.36 \pm 0.02$ \\
\hline Delphinidin-3-acetyl glucoside & $2.16 \pm 0.02$ \\
\hline Delphinidin-3-p-coumoroyl glucoside & $2.01 \pm 0.02$ \\
\hline Malvidin-3-ac. glucoside & $0.46 \pm 0.01$ \\
\hline Cyanidin-3-p-coumoroyl glucoside & $0.82 \pm 0.02$ \\
\hline Petunidin-3-p-coumoroyl glucoside & $0.61 \pm 0.01$ \\
\hline Peonidin-3-p-coumoroyl glucoside & $0.46 \pm 0.02$ \\
\hline Malvidin-3-p-coumoroyl glucoside & $7.15 \pm 0.07$ \\
\hline$\sum$ Phenolic acids & $4.24 \pm 0.09$ \\
\hline$\sum$ Flavan-3-ols & $15.52 \pm 0.11$ \\
\hline$\sum$ Flavonols & $0.45 \pm 0.04$ \\
\hline$\sum$ Anthocyanins & $21.68 \pm 0.13$ \\
\hline$\Sigma$ Total phenolic compounds & $41.89 \pm 1.43$ \\
\hline
\end{tabular}

Two flavan-3-ol monomers, (+)-catechin and (-)-epicatechin were detected in the pomace extract. We also detected a number of flavan-3-ol oligomers compounds, in a significant quantity. They showed similar UV absorbance spectra to these presented by (+)-catechin, (-)-epicatechin and (-)-epicatechin gallate and may be assigned to nonacylated procyanidins derived from (+)-catechin and (-)-epicatechin, and esterified procyanidins with gallic acid derived from (-)-epicatechin gallate [13-14]. Due to the lack of standards for these compounds we were not able to identify them individually. Their content in the extracts was expressed as procyanidins B2 equivalents. Flavan-3-ol monomers and procyanidins were mainly present in pomace seeds but also in pomace skins and steams in lower quantity.

Anthocyanin compounds had the participation of $51.75 \%$ of the total phenolic content (Table 2). Malvidin-3-p-coumoroyl-glucoside and malvidin-3-glucoside were the main anthocyanidins found in pomace extracts followed by 3-glucosides, acetyl-glucoside and 3-p-coumoroyl-glucoside derivates of peonidin, delphinidin, cyanidin and petunidin (Figure 1).

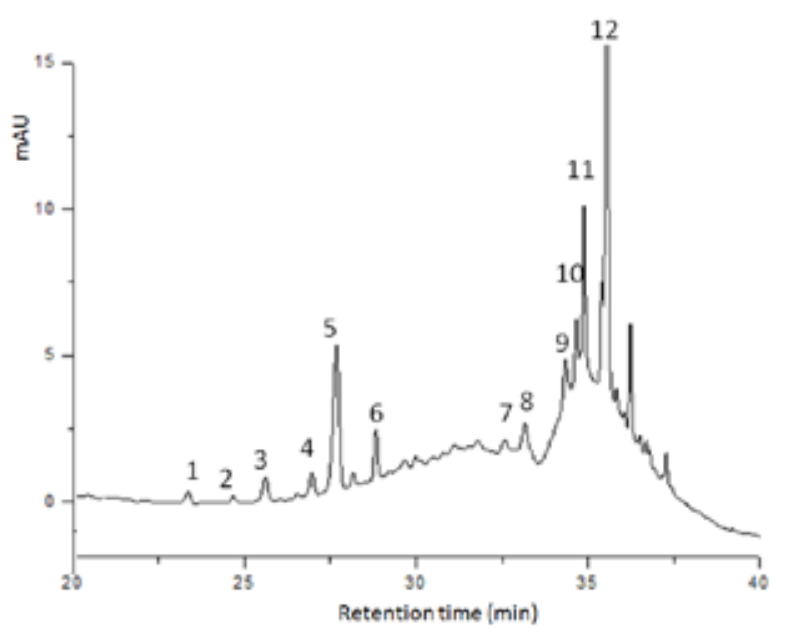

Figure 1. HPLC chromatogram of the grape pomace extract recorded at $520 \mathrm{~nm}$ : 1 delphinidin-3-glucoside, 2 cyanidin3-glucoside, 3 petunidin-3-glucoside, 4 peonidin-3-glucoside, 5 malvidin-3-glucoside, 6 delphinidin-3-acetyl glucoside, 7 delphinidin-3-p-coumoroyl glucoside, 8 malvidin-3-acetyl glucoside, 9 cyanidin-3-p-coumoroyl glucoside, 10 petunidin-3-pcoumoroyl glucoside, 11 peonidin-3- p-coumoroyl glucoside and 12 malvidin-3-p-coumoroyl glucoside)

The radical scavenging activity of the investigated extracts was estimated by DPPH test. The results are shown in Table 1 and Figure 2, expressed as $\mathrm{EC}_{50}$ value $(\mathrm{mg} / \mathrm{ml})$. The grape pomace extract showed a significant radical scavenging activity. The high linear correlation between different concentrations of grape pomace extracts and corresponding radical scavenging activities of these extracts $\left(R^{2}=0.9732\right)$ suggests that the phenolic compounds, obviously present in the extract and certainly interact with DPPH radical, are at least partially 
responsible for the strong radical scavenging activity of these extracts.

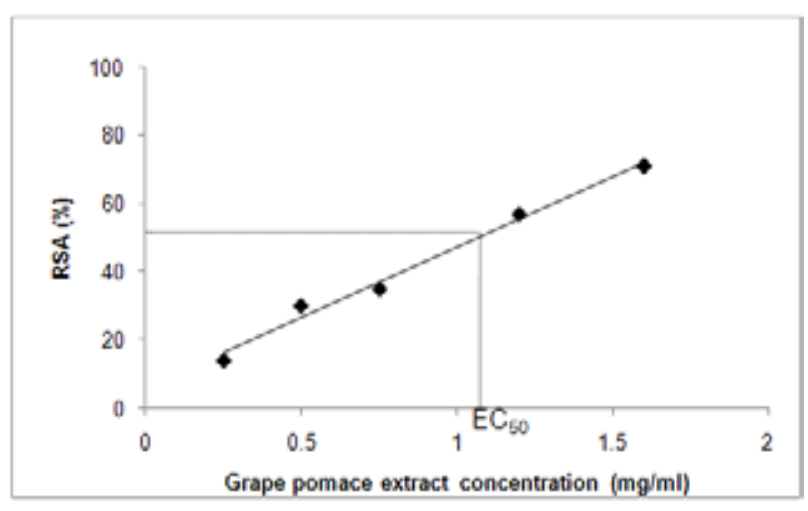

Figure 2. Radical scavenging activities (RSA) of the solutions of different grape pomace extract concentration

The analysis of the fatty acid composition of the pomace oil is performed on the GC/MS apparatus under conditions described in the experimental part. The mass fractions $(\%)$ of the identified fatty acids from the pomace oil are shown in Table 3.

Table 3. Fatty acid composition of the grape pomace

\begin{tabular}{lcc}
\hline Fatty acids & Formula & mass fractions (\%) \\
\hline Palmitic & $\mathrm{C}_{16} \mathrm{H}_{32} \mathrm{O}_{2}$ & 6,6 \\
Linoleic & $\mathrm{C}_{18} \mathrm{H}_{32} \mathrm{O}_{2}$ & 72,4 \\
Oleic & $\mathrm{C}_{18} \mathrm{H}_{34} \mathrm{O}_{2}$ & 16,3 \\
Stearic & $\mathrm{C}_{18} \mathrm{H}_{36} \mathrm{O}_{2}$ & 4,1 \\
Linolenic & $\mathrm{C}_{18} \mathrm{H}_{30} \mathrm{O}_{2}$ & $<0,1$ \\
Palmitolinoleic & $\mathrm{C}_{16} \mathrm{H}_{30} \mathrm{O}_{2}$ & $<0,1$ \\
\hline
\end{tabular}

The most common fatty acids were linoleic, oleic, palmitic and stearic acid (Figure 3). The linolenic and palmolinoleic acids were present in the concentrations below $0.1 \%$. The major fatty acid in the grape pomace oil was linoleic acid.

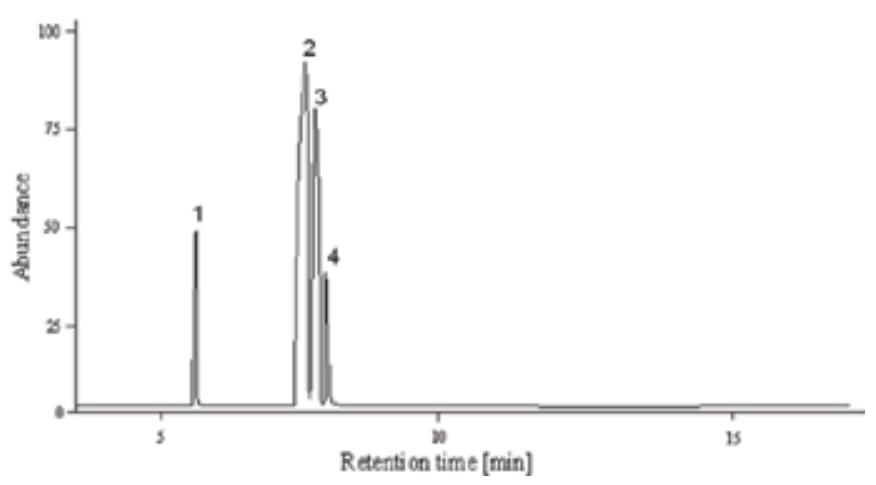

Figure 3. GC/MS chromatogram of the grape pomace oil fatty acid composition: 1 palmitic acid, 2 linoleic acid, 3 oleic acid and 4 stearic acid
The fatty acid composition of the grape pomace are similar to the oils of safflower, sunflower, soybean, maize, cotton seed, popy and tobacco, which belong to the linoleic type [5].The grape pomace oil was rather poor in linolenic acid. Low levels of linolenic acid are desired in edible oils, because high levels of this fatty acid can produce an unfavourable odour and taste in oil. Furthermore, since linolenic acid is oxidised simply due to having three double bonds on its hydrocarbon chain, the stability or shelf-life of the oil rich in linolenic acid will be short $[16,17]$. So, the grape pomace oil having low quantities of linolenic acid can be an advantage in terms of the human consumption and the shelf-life of the oil. The second abundant fatty acid in the pomace oil was oleic acid. Oleic acid, a monounsaturated fatty acid, also has great importance in terms of their nutritional implication and the effect on the oxidative stability of oils [18]. The degree of unsaturation in the grape pomace oil was over $88 \%$, coming from unsaturated fatty acids. High levels of unsaturation play an important role in lowering high blood cholesterol and also in the treatment of atherosclerosis [19].

\section{Conclusion}

The grape pomace extract had a high phenolic content. The most abundant phenolic class that was found in the grape pomace extract was anthocyanins followed by flavan-3-ols, phenolic acids (mostly hydroxycinnamoyl acids) and flavonols. As correlation calculations showed, phenol compounds are responsible for strong radical scavenging activities of the tested extracts. The grape pomace oil with a high degree of unsaturation plays an important role in human health. Due to their significant biological activities, the phenolic rich extract and the grape pomace oil can be used as additives in food and medicaments.

\section{Acknowledgments}

The present research was supported by the EU, FP7 - Regpot - 2007- 3-01, the project «Chromlab-Antioxidant» No. 204756 and by the Ministry of Education and Science of the Republic of Serbia, the project No. 34012, 31020 and 176006.

\section{References}

[1] G. Özkan, O. Sagdiç, N. G Baydar, Z. Kurumahmutoglu, Antibacterial activities and total phenolic contents of grape pomace extracts, Journal of the Science of Food and Agriculture, 84 (2004) 1807-1811.

[2] M. Anastasiadi, N. G. Chorianopoulos, G. J. E. Nychas, S. A. Haroutounian, Antilisterial activities of polyphenol-rich extracts of grapes and vinification byproducts, Journal of Agricultural and Food Chemistry, 57 (2009) 457-463.

[3] L. Butkhup, S. Chowtivannakul, R. Gaensakoo, P. Prathepha, S. Samappito, Study of the Phenolic 
Composition of Shiraz Red Grape Cultivar (Vitis vinifera L.) Cultivated in North-Eastern Thailand and Its Antioxidant and Antimicrobial Activity, South African Journal of Enology and Viticulture, 31 (2010) 89-98.

[4] J. A. Vinson, Y. A. Dabbagh, M. M. Serry, J. Jang, Plant flavonoids are powerful antioxidans using an in vitro oxidation model for heart disease, Journal of Agricultural and Food Chemistry, 43 (1995) 2800-2802.

[5] N. G. Baydar, G. Özkan, E. S. Çetin, Characterization of grape seed and pomace oil extracts, Grasas Y Aceites, 58: 1 (2007) ENERO-MARZO, 29-33.

[6] G. K. Jayaprakasha, T. Selvi, K. K. Sakariah, Antibacterial and Antioxidant Activities of Grape (Vitis vinifera) Seed Extracts, Food Research International, 36 (2003) 117-122.

[7] V. Katalinic, S. S. Mozina, D. Skroza, I. Generalic, H. Abramovic, M. Milos, I. Ljubenkov, S. Piskernik, I. Pezo, P. Terpinc, M. Boban, Polyphenolic profile, antioxidant properties and antimicrobial activity of grape skin extracts of 14 Vitis vinifera varieties grown in Dalmatia (Croatia), Food Chemistry, 119 (2010) 715-723.

[8] J. M. Souquet, B. Labarbe, C.L. Guerneve, V. Cheynier, M. Moutounet, Phenolic Composition of Grape Stems. Journal of Agricultural and Food Chemistry, 48 (2000) 1076-1080.

[9] G. Spigno, D. M. De Faveri, Antioxidants from grape stalks and marc: Influence of extraction procedure on yield, purity and antioxidant power of the extracts, Journal of Food Engineering, 78 (2007) 793-801.

[10] C. P. Passosa, R. M. Silvaa, F. A. Da Silvaa, M. A. Coimbrab, C. M. Silvaa, Enhancement of the supercritical fluid extraction of grape seed oil by using enzymatically pre-treated seed, Journal of Supercritical Fluids (2008), doi:10.1016/j.supflu.2008.11.001.

[11] B. C. Radovanović, A. S. Milenković-Anđelković, A. Radovanović, M. Z. Anđelković, Antioxidant and
Antimicrobial Activity of Polyphenol Extracts from Wild Berry Fruits grown in Southeast Serbia, Tropical Journal of Pharmaceutical Research, 12 (2013) 813-819.

[12] M. Andjelkovic, B. Radovanovic, A. Radovanovic, A. M. Andjelkovic, Changes in Polyphenolic Content and Antioxidant Activity of Grapes cv Vranac During Ripening. South African Journal of Enology and Viticulture, 34 (2013) 147-155.

[13] T. Escribano-Bailon, Y. Gutierrez-Fernandez, J. C. Rivas-Gonzalo, C. Santos-Buelga, Characterization of Procyanidins of Vitis vinifera Variety Tinta del Pais Grape Seeds, Journal of Agricultural and Food Chemistry, 40 (1992) 1794-1799.

[14] E. Revilla, J. M. Ryan, Analysis of several phenolic compounds with potential antioxidant properties in grape extracts and wines by high-performance liquid chromatography-photodiode array detection without sample preparation, Journal of Chromatography A, 881 (2000) 461-469.

[15] P. Iacopini, M. Baldi, P. Storchi, L. Sebastiani, Catechin, epicatechin, quercetin, rutin and resveratrol in red grape: Content, in vitro antioxidant activity and interactions. Journal of Food Composition Analysis, 21 (2008) 589-598.

[16] J. L. Hall, T. J. Flower, R. M. Roberts, Plant Cell Structure and Metabolism. Longman Inc., New York 1981.

[17] P. A. Mayes, Harper's Review of Biochemistry, Metabolism of Lipid en Fatty Acids, Medical Pub. Inc.,California 1983.

[18] R. Aparicio, L. Roda, M. A. Albi, F. Gutierrez, Effect of various compounds on virgin olive oil stability measured by Rancimat, Journal of Agricultural and Food Chemistry, 47 (1999) 4150-4155.

[19] J. D. Axtell, in Plant Breeding II, Breeding for improvement nutritional quality, en Frey K. J. (Ed.), The lowa State University Press, lowa 1981, p. 497.

\section{Izvod}

\section{ODREĐIVANJE BIOLOŠKI AKTIVNIH SASTOJAKA KOMINE GROŽĐA SORTE VRANAC ZA POTENCIJALNU UPOTREBU U PREHRAMBENOJ I FARMACEUTSKOJ INDUSTRIJI}

Marko Anđelković, Blaga Radovanović ${ }^{1}$, Ana Milenković Anđelković1,

Vladimir Radovanović ${ }^{1}$, Aleksandra Zarubica ${ }^{1}$, Nikola Stojković1 ${ }^{\text {, Vesna Nikolić }}{ }^{2}$

1 Prirodno-matematički fakultet, Katedra za hemiju, Univerzitet u Nišu, Niš, Srbija

2 Tehnološki fakultet, Univerzitet u Nišu, Leskovac, Srbija

Proizvodnja vina generiše značajne količine otpada - komine (uglavnom semenke, pokožice i peteljke grožđa). U komini se i dalje mogu naći značajne količine bioaktivnih supstanci kao što su fenolna jedinjenja. Fenolni sastav $i$ antioksidativna aktivnost komine, dobijene u procesu vinifikacije crvene vinske sorte grožđa Vranac (Vitis vinifera L.), ispitivani su sa ciljem da se ustanove upotrebljivi (vredni) sastojci. Ekstrakti komine analizirani su spektrofotometrijskom i RP-HPLC metodom u cilju određivanja fenolnog sastava, a antioksidativna aktivnost određena je DPPH testom. Ulje dobijeno od komine podvrgnuto je GC/MS analizi kako bi se ustanovio njegov masnokiselinski sastav. Jedinjenja fenola, kako korelacioni proračuni pokazuju $\left(R^{2}=0,9732\right)$, odgovorna su za jaku antioksidativnu aktivnost ekstrakata komine $(1.160 \pm 0,03 \mathrm{mg} \mathrm{DM} / \mathrm{ml})$. Ulje komine grožđa sadrži visok stepen nezasićenih masnih kiselina (preko 88\%) i igra važnu ulogu za zdravlje čoveka. Ekstrakti bogati fenolnim jedinjenjima i ulje od komine grožđa mogu se upotrebiti kao aditivi u hrani i farmakološkim proizvodima, zbog značajne biološke aktivnosti koju pokazuju.

(ORIGINALNI NAUČNI RAD) UDK 663.26:66.061.34

Ključne reči: komina grožđa, semenke grožđa, fenolna jedinjenja, antioksidativna aktivnost, masne kiseline. 